\title{
Spotlight on the role of the news media
}

The push by the PNG government for a 'responsible and accountable' media has put the country's industry in the public spotlight. Several seminars and debates have highlighted the role as a public watchdog.

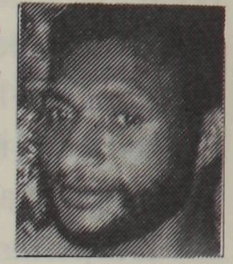

\section{By KEVIN PAMBA}

THE PAPUA NEW GUINEA media industry is now under the microscope of policy-makers and the public. A National Information and Communication Policy was formulated in 1993 when the late Manus MP, Martin Thompson, was the Communication and Information Minister. In late 1995, the Constitutional Review Commission put in place a media accountability sub-committee given the task to look into how the media could be made to fall in line with the government's interpretation of 'responsible and accountable' media.

With these developments, a number of seminars and lively debates have been held focusing on the workings of the media industry. During these gatherings and debates, critics have pointed out two things: The importance of the watchdog role of the media, and the need to have well-trained personnel who can be critical and yet be wary of what they put out for public assumption.

On May 23, during the presentation of the inaugural Pacific Investigative Journalism Award at the University of Papua New Guinea, sponsored by the South Pacific Centre for Communication and Information in Development (SPCenCIID), Communication and Information Minister Joseph Egilio said:

Although there is some very good journalism at times at time in PNG, there is a shortage of skilled and experienced journalists who can tackle sensitive stories which need painstaking research.

For investigative journalism to be effective in a democracy, the investigators themselves need to be skilled. They need a far higher level of accuracy, ability to research with patient doggedness and a facility to 
write analytically and with perception.

Egilio quoted Sir Paulias Matane who had strongly investigative journalism at a seminar sponsored by SPCencIID last year. Sir Paulias had said investigative journalists would be the 'saviours of the nation'. Egilio said the nation's investigators should not just be concentrating on corruption or maladministration. Politics, the economy, social issues, health and many other issues were also traditionally examined by investigative journalists.

Said Egilio: 'Investigative journalists are reformers. They seek to improve our system by pointing out shortcomings. By spotlighting specific abuses of particular policies or programs, the investigative reporter provides policy makers with the opportunity to take corrective action.' He said investigative reporting exposes shortcomings of our democratic system and contributes to reforms and changes to policies that may be harmful.

It is therefore a contribution to education of the public process that is necessary for national development, he said. Frequently in the past journalists had uncovered some important developments in PNG. The logging inquiries of the mid-1980s leading to the Barnett Commission of Inquiry was an example often cited in this connection.

Egilio added that sometimes investigative reporters might miscalculate the boundaries of civic morality. Sometimes the public or policy makers responded with indifference to exposes of alleged wrongdoing. He said perhaps the villains and victims are ill-defined or the revelations fail to appeal to widely held societal norms or the problem exposed is mundane or intractable.

Therefore, Egilio said, in such cases miscalculation can be a source of frustration to the investigative journalists but nevertheless their persistence was vital. Egilio then stressed the importance of training in the industry and quoted an excerpt from the National Communication Policy which says:

The national communication system can only perform as well as the people who run it.

Training in a wide variety of communications skills is the key to success. The purpose of training embraces the entire communication system. Authors, scriptwriters, journalists and editors must prepare for the content of the media. Engineers, technicians and maintenance personnel are required for the telecommunication and broadcast networks; printers and compositors for the press rooms of newspapers, magazines and books; cameramen, directors and technicians for the film and television studios.

Information and extension officers need training in the process of communication and in the use of technological aids. Granted the com- 


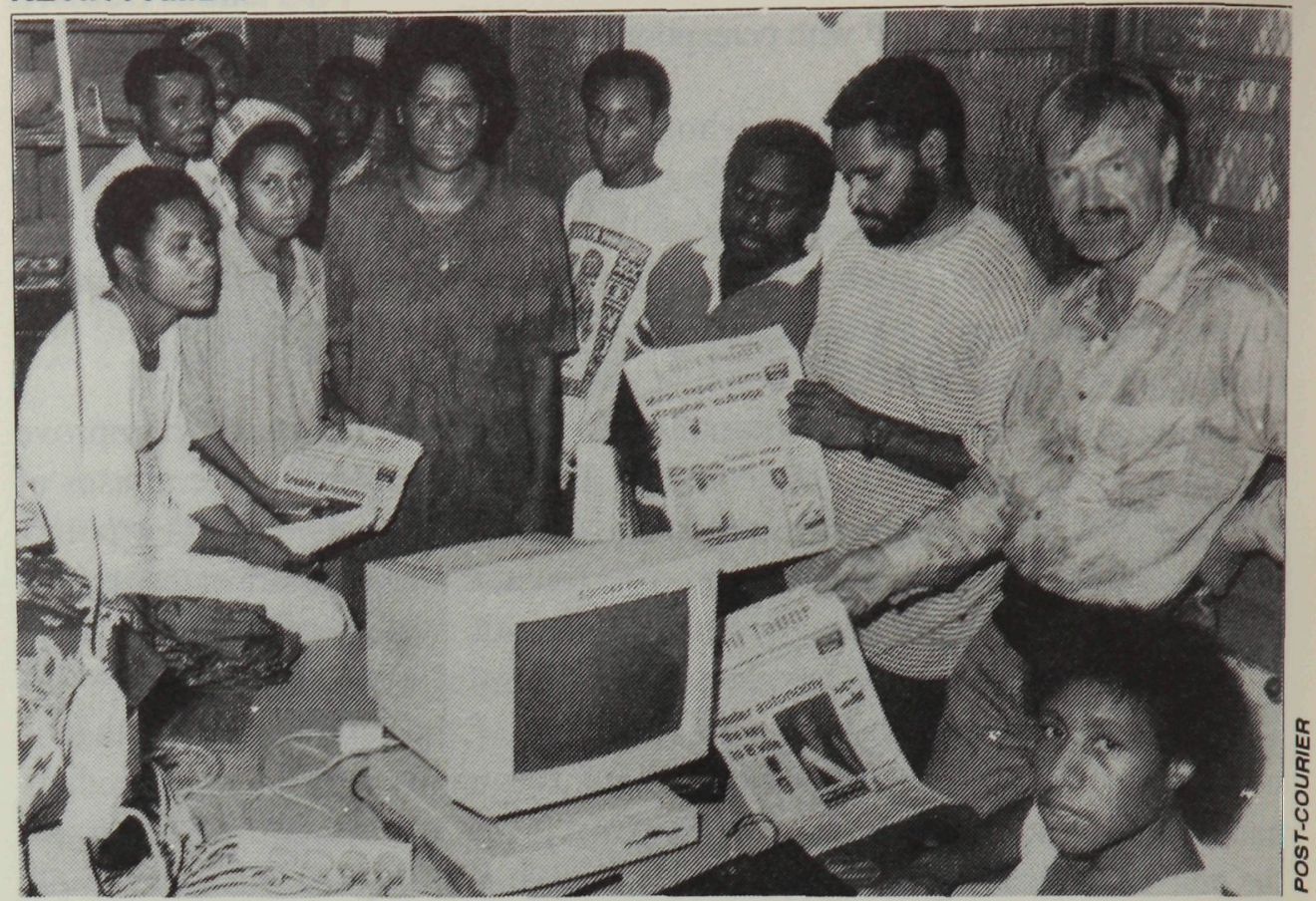

\section{Staff of the award-winning Uni Tavur newspaper ... training is important.}

plexities and rapid changes in the modern communication, expertise is needed in economic evaluation, planning and management.

BHP-PNG general manager Kipling Uiari, who is also chairman of the PNG Business Council, told the 'Media Freedom' seminar in February that PNG journalists, camera crews, producers and technicians needed further training or exposure to some other intensive working environments. He said the business community recognised the importance of training within the media industry and its personnel. Uiari further suggested that the media and business houses use their overseas contacts to have PNG writers, technicians, broadcasters and producers go abroad on attachments so that they could gain valuable experience.

'Not once did [Mr Uiari] say anything about the two journalism training institutions - Divine Word Institute in Madang and SPCenCIID at UPNG that train young journalists in the country,' SPCenCIID journalism lecturer Sorariba Nash said in the April issue of the centre's newsletter, Ita Diba. 'I believe that the two institutions need all the support they can get from every media industry and all the business houses in the country,' Nash said.

The Catholic Church-funded and run DWI offers communication arts diploma and degree programs while the UPNG program offers a two-year diploma and a four-year degree program, and a half-year graduate Certificate in Investigative Journalism. Nash said that, unlike the print component of the 
UPNG journalism program which had been revolutionised through computer technology due to generous outside support, the electronic media component had had little luck in terms of changes.

His colleague, David Robie, says that after 21 years the UPNG journalism program had received little support from the state education funding sources. In the last few years, it needed to rely on outside donations. Robie says journalism has not been a priority area in national education plans despite its vital role. Yet the centre publishes Uni Tavur, the journalism training newspaper that won the Ossie Award for student journalism in 1995.

SPCenCIID head Rhonda Eva says the programs of the centre, including journalism, have been effected by the annual budget allocations to UPNG. She said Egilio was surprised to realise that 'we exist'. But he was pleased with the developments taking place there. He said efforts and the commitment of SPCenCIID in promoting investigative journalism should be recognised and welcomed.

'I commend the SPCenCIID for its efforts in promoting excellence in investigative journalism and also for ensuring some recognition for journalists of PNG and the Pacific who have embarked on a difficult and sometimes thankless field of journalism,' Egilio said.

The centre in 1995 introduced the South Pacific region's first graduate Certificate in Investigative Journalism course in an attempt to raise professional standards and also in 1994 launched this journal, Pacific Journalism Review, which devotes some space to investigative journalism. This year the centre sponsored the inaugural Pacific Investigative Journalism Award. 'All of these activities, I am pleased to say, are very much in keeping with the National Communication and Information Policy. The centre seems to be taking the policy seriously in its development communication for the future,' Egilio said.

The centre runs journalism, mass media, public relations, library and information studies programs. Since its beginning with New Zealand government funds in 1974 , the UPNG journalism program has made a significant contribution in tertiary journalism education in the South Pacific. It has produced more than 150 graduates from within PNG and the Pacific.

Kevin Pamba is a journalist on The National and former editor of Uni Tavur. This article was published in the daily newspaper's 3 June 1996 issue. 